Grębowiec Mariusz

Szkoła Gtówna Gospodarstwa Wiejskiego w Warszawie

\title{
Rola współczesnych innowacji sektora owoców i warzyw w procesie postrzegania i podejmowania decyzji nabywczych przez konsumentów
}

\section{THE ROLE MODERN INNOVATIONS IN THE FRUIT AND VEGETABLE SECTOR I THE PROCESS OF PERCEIVING AND PURCHASING DECISUIONS BY CONSUMERS}

$W$ artykule dokonano próby oceny innowacyjności sektora owoców $i$ warzyw $w$ opinii polskich konsumentów. Bazujac na dostępnej literaturze, artykułach i czasopismach branżowych oraz informacjach opublikowanych na stronach internetowych scharakteryzowano zmiany na polskim rynku owoców $i$ warzyw, innowacyjność sektora owoców $i$ warzyw, rodzaje innowacji zwiazanych $z$ nowymi technologiami $i$ procesami oraz z nowymi metodami marketingowymi $i$ organizacyjnymi, a także wskazano trendy $i$ bariery nabywcze konsumentów $w$ sektorze owocowowarzywnym. Dla petnego zobrazowania stopnia znajomości $i$ rozpoznawalności wybranych innowacji oraz stosunku do tego typu produktów konsumenta przeprowadzono badania ankietowe.

Słowa kluczowe: innowacja, rynek, konsument, owoce i warzywa, innowacyjne produkty żywnościowe

\section{Wstęp}

$\mathrm{Na}$ współczesnym rynku produktów spożywczych nieustannie zachodzą zmiany, głównie za sprawą zmieniających się wciąż preferencji konsumentów, jak również konkurujących ze sobą jednostek produkcyjnych. Przedsiębiorstwa dostrzegają że wprowadzenie innowacji stało się już koniecznością, aby utrzymać się na rynku.

Uzyskanie jak największej liczby informacji związanych z konsumentem i jego zachowaniem na rynku jest dzisiaj kluczem do sukcesu. Przedsiębiorstwo chcąc funkcjonować oraz odnosić sukcesy na rynku, musi spojrzeć na swoje produkty oczami nabywców. Firmy powinny ciągle analizować i oceniać swoją ofertę oraz doskonalić ją, poprzez wdrożenie nowych właściwości produktów, istotnych dla konsumenta oraz eliminować niepożądane atrybuty.

Rynek FMCG (Fast-Moving Consumer Goods) w Polsce wprowadza każdego roku kilkaset nowych produktów w różnych grupach żywności, co jest odzwierciedleniem ciagłych przemian tego rynku, jednak duża liczba niepomyślnie wprowadzonych nowości pokazuje jak wymagający i trudny jest to rynek dla producentów. Dlatego też pojęcie innowacyjności podmiotów rynkowych to kluczowy element powodzenia i dalszego rozwoju. Wprowadzanie innowacji produktowych przez firmy, pozwala im na utrzymanie pozycji na rynku. Jednak wdrożenie nowości produktowych wsparte musi być odpowiednimi działaniami marketingowymi i technologicznymi. Pierwsze odnoszą 
się do rozpoznawalności danego produktu na rynku w oczach nabywców, natomiast drugie odpowiadają za produkt, i to najwyższej klasy jakości. Nie należy zapominać o innowacjach procesowych i organizacyjnych. To dzięki nim koszty transportu i produkcji maleją, zaś dobre stosunki między kadrą kierowniczą, a pracownikami poprawiają komfort i wydajność pracy.

\section{Pojęcie i znaczenie innowacji}

W literaturze przedmiotu istnieje wiele definicji innowacji. Pierwszym, który zdefiniował to pojęcie, był austriacki ekonomista i teoretyk Joseph A. Schumpeter. Miało to miejsce jeszcze w 1911 roku$^{1}$. Ograniczył on rozumienie innowacji do wdrożenia nowego procesu lub do komercjalizacji nowego produktu. Mimo, że doceniał znaczenie wiedzy, to nie prowadził badań nad powiązaniami między innowacjami, a wiedzą. Obecnie, postrzeganie i relacje są zupełnie inne, to wiedza i informacja stanowią podstawową wartość ${ }^{2}$. Innowacje powinny zwiększać korzyści dla konsumentów lub przyczyniać się do obniżenia kosztów. Dzięki innowacjom możliwe jest osiaggnięcie obu tych efektów. Istnieje wiele klasyfikacji innowacji. Traktując innowacje jako obiekt badań, z punktu widzenia powodowanych przez nie następstw (skutków), wyróżniono innowacje strategiczne i taktyczne. Pierwsze $\mathrm{z}$ nich odnoszą się do przedsięwzięć innowacyjnych o długofalowym charakterze i służą do realizacji celów strategicznych. Innowacje taktyczne dotyczą bieżących zmian w wyrobach, produkcji technologii i organizacji pracy. Pozwalają one na poprawę efektywności gospodarowania w przedsiębiorstwach. Ze względu na kryterium podziału oryginalności zmian, wskazano na dwie grupy innowacji, są to: innowacje kreatywne, polegające na dokonaniu odkrycia lub wynalazku i jego późniejsze pierwsze praktyczne zastosowanie twórcze ${ }^{3}$. Drugą grupę stanowią innowacje imitujące, polegające na odtwarzaniu i naśladownictwie oryginalnych zmian prowadzących do określonych korzyści w danym czasie i miejscu.

W międzynarodowej metodologii badań odnoszących się do innowacyjnych przedsiębiorstw przyjęto kryterium przedmiotowe i wyodrębniło cztery podstawowe typy innowacji ${ }^{4}$ : produktowe, marketingowe, procesowe oraz organizacyjne. Między wyżej wymienionymi grupami innowacji występują silne powiązania. Wdrożenie innowacji procesowych i produktowych wpływa na innowacje organizacyjne. Natomiast innowacje marketingowe mogą zwiększać zdolność firmy do rozwoju nowych produktów, jak również mogą kształtować zindywidualizowaną ofertę. Powodują repozycjonowanie marek, modyfikacje w sposobie dystrybucji, zmiany charakteru relacji $\mathrm{z}$ nabywcami. Efekt takich zmian, to m.in. poprawa wyników ekonomicznych przedsiębiorstwa.

Wyjaśniając istotę innowacji, należy wspomnieć o terminie innowacyjność. Według Grzybowskiej, innowacje posiadają charakter podmiotowy, co innego innowacyjność,

1 Szymańska A. I.: Innowacyjność produktowa przedsiębiorstw produkcyjnych a preferencja konsumentów. Prace Komisji Geografii Przemysłu Polskiego Towarzystwa Geograficznego, 2012(20), s. 147-161.

${ }^{2}$ Lemanowicz M.: Aktywność innowacyjna przedsiębiorstw w Polsce ze szczególnym uwzględnieniem branży spożywczej. Roczniki Naukowe Stowarzyszenia Ekonomistów Rolnictwa i Agrobiznesu 2014, 16(6), $307-312$

${ }^{3}$ Baruk J.: Zarzadzanie wiedzq i innowacjami. Wydawnictwo Adam Marszałek, Toruń 2006, s.26.

${ }^{4}$ Oslo Manual : Guidelines for Collecting and Interpreting Innovation Data. 3rd Edition. OECD and Eurostat 2005 
która wiąże sie z procesem i działaniem, czego efektem są innowacje. Nie ma powszechnie ustalonej jednolitej definicji innowacyjności, tak jak i w przypadku terminu innowacja ${ }^{5}$. Innowacyjność to proces polegający na ciagłym wprowadzaniu zmian jakościowych w sferze organizacji pracy, technologii, zarządzania i marketingu. Wymienione zmiany prowadzą do powstawania nowego produktu, jak również jego znacznej modernizacji.

\section{Przykładowe działania innowacyjne podejmowane w sektorze owocowo-warzywnym w Polsce}

Polscy konsumenci są coraz bardziej zapracowani i zabiegani. Nie mają czasu na czasochłonne gotowanie czy zakupy, a z drugiej strony starają się bardziej zadbać o to, aby spożywane w pośpiechu posiłki były pożywne, zdrowe i wygodne. Zaobserwowano silny trend zwany convenience, stąd wiele firm wdraża coraz więcej innowacji w sektorze owoców i warzyw. Zdrowe przekąski i innowacyjne produkty do spożycia „,W biegu" stały się integralną częścią diety sporej grupy nabywców. Wprowadzenie kolejnych innowacji w tym sektorze gospodarki pozwoli na zwiększenie spożycia owoców i warzyw w Polsce oraz powiększy sprzedaż w segmencie przekąsek i soków NFC (soki naturalnie mętne), a także mrożonych gotowych dań warzywnych i owocowych. Do pozostałych czynników wpływających na zmianę zachowania konsumentów na rynku innowacji owoców i warzyw zaliczono spadek bezrobocia i wzrost zamożności, czyli wzrost poziomu życia i konsumpcji, wydłużenie życia społeczeństwa, zmiany w modelu funkcjonowania gospodarstw domowych, globalizacja, wyższa aktywność zawodowa kobiet, dbałość o zdrowie oraz wyższe wykształcenie, większa świadomość konsumentów oraz dbałość o ochronę środowiska. Wymienione determinanty stwarzają kolejne powody, aby firmy kreowały nowe produkty, biorąc pod uwagę powyższe trendy celem zaspokojenia potrzeb konsumentów.

Wprowadzanie innowacji w sektorze owoców i warzyw wiąże się z rozwojem innowacyjności przedsiębiorstwa, czego wynikiem jest większy udział sprzedaży produktów innowacyjnych w całym sektorze spożywczym. Stare odmiany owoców i warzyw są sukcesywnie wypierane przez nowe, które pojawiają się na polskim rynku. Cechują się one lepszymi walorami jakościowymi, większą trwałością w obrocie handlowym, mniejszą podatnością na choroby grzybowe, czy też posiadają dłuższy okres przechowywania ${ }^{6}$. Mało przetworzone owoce i warzywa są półproduktami zbliżonymi pod względem naturalności i świeżości do surowców o trwałości zapewniającej bezpieczeństwo spożycia i dystrybucji przez co najmniej 4-7 dni. Celem zabezpieczenia półproduktów przed rozwojem mikroflory zwykle pakuje się je w atmosferze modyfikowanej, o zmniejszonej zawartości tlenu i podwyższonej dwutlenku węgla. Zanurzenie np. plastrów warzyw w roztworach kwasu nadoctowego lub w przypadku owoców w kwasie askorbinowym zwiększa pojemność przeciwutleniającą

${ }^{5}$ Grzybowska B.: Innowacyjność przemysłu spożywczego - ujęcie regionalne. Wydawnictwo UWM, Olsztyn 2012, s. 89

${ }^{6}$ Kruczyńska D. : Nowe odmiany jabłoni. Wydawnictwo Hortpress, Warszawa 2008. 
produkt, a po zapakowaniu w atmosferze modyfikowanej zapobiega degradacji składników odżywczych ${ }^{7}$.

Ta wiedza pomaga przedsiębiorstwom we wdrażaniu innowacyjnych produktów. Przykładem może być Firma Marwit, która wypuściła na rynek przekąski owocowowarzywne sprzedawane w dwukomorowych pojemnikach w czterech wariantach smakowych. Przykładowa kompozycja smakowa to: jabłko, winogrono, marchewka i pomidor.

Innym przykładem jest Spółka Green Factory podjęła produkcję oraz sprzedaż pociętych, umytych, spakowanych i gotowych do spożycia mieszanek sałat. Kolejnymi innowacjami były tzw.: lunch boksy, czyli sałatki $\mathrm{z}$ dodatkami oraz $\mathrm{z}$ dresingiem i plastikowymi sztućcami. Podobne innowacje znane się już dość dobrze w państwach Europy Zachodniej, jednak ich pozycjonowanie produktu na krajowym rynku pozostaje wciąż nowością (www.portalspozywczy.pl/owoce-warzywa/wiadomosci/sektorowocow-i-warzyw-rozwija-sie-w-rytmie convenience,138286.html, dostęp w dniu 18.06.2017 r.).

Owoce i warzywa najlepiej konsumować oczywiście w stanie świeżym, w związku z ich niewielką trwałością i produkcją sezonową, większość owoców i warzyw poddawana jest obróbce technologicznej, celem ich utrwalenia i przetworzenia ${ }^{8}$. Jedną $z$ najlepiej rozwijających się kategorii sektora przetwórstwa owoców i warzyw są soki nie wytwarzane z koncentratu (NFC - Not From Concentrate). Odnotowują one wzrost sprzedaży na poziomie $7 \%$ rocznie. Soki tłoczone, pomimo wyższej ceny zdobywają popularność wśród konsumentów ze względu na większą zawartość witamin i składników mineralnych. Firma Hortex w 2016 roku wprowadziła nową linię soków tłoczonych w różnych wariantach smakowych. Mieszanie soków różnych gatunków daje możliwość otrzymania produktów o dużej zawartości związków prozdrowotnych. Przykładowo połączenie soku $\mathrm{z}$ limonki bogatego w flawony $\mathrm{z}$ sokiem $\mathrm{z}$ aronii, bogatego w antocyjany.

Kolejną dobrze rozwijającą się kategorią produkcji, są dżemy. Rynek ten rośnie w tempie blisko 3\% rocznie. Wielu producentów wprowadziło innowacje związane z coraz większą różnorodnością używanych do produkcji surowców. Dawtona w 2015 roku wprowadziła dżem pomidorowy. Maspex w 2016 roku wprowadził dżemy marki Łowicz, wytwarzane z owoców o prozdrowotnych właściwościach takich jak czarny bez, rokitnik czy dzika róża, a rok później poszerzył swoją innowacyjną ofertę o dżemy z dodatkami kwiatów jadalnych (http://www.portalspozywczy.pl/owocewarzywa/wiadomosci/sektor-owocow-i-warzyw-rozwija-sie-w-rytmie-

convenience, 138286.html, dostęp w dniu 18.06.2017 r.).

Innym typem działań innowacyjnych mogą być innowacyjne procesy i technologie. Zastosowanie nowych procesów i technologii pozwoliło wydłużyć trwałość produktów spożywczych w tym owoców i warzyw, zwiększyć ich bezpieczeństwo i jednocześnie wytworzyć wyroby istotnie różne od występujących już na rynku. Innowacje w zakresie procesu produkcji oraz technologii żywności w różnym stopniu akceptowane są przez

\footnotetext{
${ }^{7}$ Czapski J.: Owoce $i$ warzywa oraz ich przetwory. W: Żywność prozdrowotna - składniki i technologia (red. J, Czapski, D. Górecka). Wydawnictwo Uniwersytetu Przyrodniczego w Poznaniu, Poznań 2015. s. 87-89

${ }^{8}$ Grębowiec M.: Znaczenie innowacji produktowych $w$ rozwoju przedsiębiorstw na przykładzie branży owocowo-warzywnej. Zeszyty Naukowe Szkoły Głównej Gospodarstwa Wiejskiego w Warszawie - Problemy Rolnictwa Światowego 2011, 11(26), nr 2, 26-36
} 
konsumenta. Stosuje się między innymi inżynierię genetyczną polegającą na modyfikacji roślin. Technologia ta polega na wprowadzeniu lub usunięciu określonych genów, aby zwiększyć odporność roślin na infekcje wirusowe, bakteryjne, szkodniki czy herbicydy, ale przede wszystkim polega na wydłużeniu ich trwałości ${ }^{9}$.

Wiele nowych procesów technologicznych stosowanych jest w produkcji żywności wygodnej, w tym wielu przekąsek warzywnych, owocowych, zup, kremów, bulionów, ale również koncentratów warzywnych. Stosowanie innowacyjnych technologii to między innymi niekonwencjonalne metody ogrzewania, nietermiczne metody przetwarzania, dodatek naturalnych substancji niszczących lub hamujących rozwój drobnoustrojów oraz korzystanie $\mathrm{z}$ opakowań aktywnych ${ }^{10}$. Ciekawym procesem zmian zachodzącym w przedsiębiorstwach, są technologie związane z dalszą obróbką odpadów owocowych i warzywnych. Mogą to być np. wytłoki, bo tak należy nazwać powstający odpad, zawierający duże ilości związków prozdrowotnych. Powstają podczas tłoczenia soku oraz nasion. Wytłoki owocowe po poddaniu procesowi ekstrakcji (dobre źródło związków fenolowych) dodawane są do różnych produktów, chociażby do soków jabłkowych, natomiast wytłoki suszone są dobrym komponentem różnych wyrobów i posiadają większą wytrzymałość podczas przechowywania w porównaniu z suszonymi owocami. Firmy wykorzystują liście i ogonki brokułów jako dodatek do naparów z herbaty (zwiększenie zawartości polifenoli i glukozynolanów w produkcie), wytłoki jabłkowe używane są do produkcji pektyn, ekstraktów o dużej pojemności przeciwutleniającej, preparatów zagęszczających, a wytłoki powstające z kolorowych owoców, do otrzymywania preparatów barwiących ${ }^{11}$.

Na rynku owoców i warzyw, jak również w segmencie przetworów owocowowarzywnym oprócz wprowadzenia przez producentów innowacji produktowych, zauważalny jest wzrost innowacyjnych metod marketingowych. Można do nich zaliczyć zmiany w wielkości, kształcie, rodzaju i masie opakowań. Innowacje te polegają także na zmianie materiału wykorzystywanego do produkcji opakowań, umożliwiającego przygotowanie przetworzonych owoców i warzyw np. w kuchence mikrofalowej. Wykonane są ze specjalnej folii, która pod wpływem ciepła dostarczonego z mikrofali gotuje produkty. W obszarze opakowań mogą zostać wprowadzone dodatkowo innowacje związane z wielkością opakowania. Producenci muszą dostosować wielkość opakowania w zależności od grupy konsumentów do której kierowany jest dany produkt. Zmniejszenie opakowania powiązane jest ze zmniejszeniem ilości produktu, a przez to ze spadkiem ceny za produkt. Przy odpowiednim sposobie wprowadzenia zmian cenowych, przedsiębiorstwo może wpłynąć na wzrost sprzedaży produktów ${ }^{12}$.

W opakowaniach można dokonać również innowacji w zakresie zmian szaty graficznej, dzięki niej producent komunikuje się z konsumentem. Między innymi firma

\footnotetext{
9 Jeżewska-Zychowicz M.:, Uwarunkowania akceptacji konsumenckiej innowacyjnych produktów żywnościowych. Żywność. Nauka. Technologia. Jakość 2014, 6(97), 5-17

${ }^{10}$ Targosz R.: Promocja innowacyjnych rozwiazań technicznych $i$ organizacyjnych $w$ sektorze przetwórstwa żywności. Wydawnictwo SGGW, Warszawa 2015, s. 24.

${ }^{11}$ Czapski J.: Owoce $i$ warzywa oraz ich przetwory. W: Żywność prozdrowotna - składniki i technologia (red. J, Czapski, D. Górecka). Wydawnictwo Uniwersytetu Przyrodniczego w Poznaniu, Poznań 2015. s. 87-89

12 Grębowiec M.: Znaczenie innowacji produktowych $w$ rozwoju przedsiębiorstw na przyktadzie branży owocowo-warzywnej. Zeszyty Naukowe Szkoły Głównej Gospodarstwa Wiejskiego w Warszawie - Problemy Rolnictwa Światowego 2011, 11(26), nr 2, 26-36
} 
Agros Nova ${ }^{13}$ zmodyfikowała logo marki Łowicz. Spółka najpierw zajmowała się produkcją dżemów, a następnie poszerzyła swój asortyment o sosy, koncentraty czy też zupy gotowe, stąd konieczność wprowadzenia logo bez wisienek, które jest bardziej uniwersalne.

Ważnym czynnikiem mającym wpływ na działalność innowacyjną przedsiębiorstw jest także ich kultura organizacyjna. Określa się nią sposób myślenia oraz działania pracowników. Czynniki innowacyjności wewnątrz przedsiębiorstw zależą bardzo często od osobowościowych cech zarządzających, ale również od zaangażowania personelu oraz odpowiedniego kontrolowania i zarządzania zasobami materiałowymi, a także infrastrukturą firmy ${ }^{14}$. Duża konkurencja wymusza w przedsiębiorstwach poszukiwania nowych rozwiązań, ale to człowiek jest bodźcem napędzającym wszystkie procesy, dlatego wymóg osobistego kontaktu pomiędzy przełożonym a pracownikami oraz eliminacja wszelkich wewnętrznych barier komunikacyjnych jest konieczna ${ }^{15}$.

\section{Material i metodologia badań}

Dla lepszego poznania preferencji i procesu postrzegania innowacyjności sektora owoców i warzyw w Polsce z punktu widzenia konsumenta, przeprowadzono badanie empiryczne. Zastosowano w nich metodę badań ankietowych, wykorzystując technikę ankiety internetowej. Badanie przeprowadzono w grudniu 2017 roku. Wzięło w nim udział 502 osoby w różnym przedziale wiekowym, dochodowym itp. Badanie miało charakter anonimowy. Opiniodawcami były osoby przypadkowo dobrane do próby. Badania opracowano przy pomocy arkusza kalkulacyjnego programu Microsoft Office Excel, a wyniki szczegółowo omówiono i przedstawiono w formie wykresów.

Badana próba składała się w większości $(62,4 \%)$ z kobiet, zaś mężczyźni stanowili $37,6 \%$ ankietowanych Najliczniejszą grupę respondentów stanowiły osoby w wieku do 25 lat (53\%), natomiast najmniej liczebną osoby powyżej 56 roku życia $(6,9 \%)$. Pozostałą część stanowiły osoby z przedziału 25-55 lat, w tym z przedziału 25-40 lat (28,2\%), a z przedziału 41-55 lat było $11,9 \%$ wszystkich ankietowanych.

Większość badanych posiadało wyższe wykształcenie $(77,2 \%)$, średnim wykształceniem legitymowało się $13,9 \%$ badanych. Zaledwie 5,9\% podało, że posiada wykształcenie zawodowe, a 3\%, wykształcenie podstawowe

Sytuacja materialna ankietowanych kształtowała się na zbliżonym poziomie. Najwięcej badanych $(25,7 \%)$ zadeklarowało dochód z przedziału 1500-2000 zł. netto miesięcznie na osobę, natomiast najmniej, bo tylko $11,4 \%$ osoby określiły swój miesięczny dochód netto na osobę w przedziale 2501-3000 zł. 22,3\% zaznaczyło, że ich dochody miesięczne netto na osobę wynosiły 2001-2500 zł. Tyle samo respondentów określiło dochód poniżej 1500 zł. Pozostałe 18,3\% badanych posiadało dochód powyżej 3000 zł. netto miesięcznie na osobę.

\footnotetext{
${ }^{13}$ W lipcu 2015 roku Firma Agros Nova sprzedała wybrane aktywa Grupie Maspex Wadowice, w tym marki: Łowicz, Krakus, Kotlin, DrWitt, Włocławek, Tarczyn, Fruktus.

${ }^{14}$ Barczak B., Walas-Trębacz J.: Działalność innowacyjna sektora MSP - determinanty rozwoju. Prace i Materiały Wydziału Zarządzania Uniwersytetu Gdańskiego 2005, nr 4, 407.

${ }^{15}$ Tylżanowski R.: Determinanty innowacyjności polskich przedsiębiorstw. W: Innowacyjność organizacji $w$ strategii intelektualnego i zrównoważonego rozwoju (red. J. Wiśniewska, K. Janasz). Wydawnictwo Difin Warszawa. 2012, s. 77.
} 


\section{Wyniki badań}

Wiedza konsumentów o produktach innowacyjnych sektora owoców i warzyw oraz motywy postępowania w procesie ich akceptacji

Badania na temat innowacyjnych produktów rozpoczęto od pozyskania informacji od respondentów na temat pierwszego skojarzenia wiążącego się z hasłem - ,innowacja w sektorze owoców i warzyw". Ponad połowa $(52,1 \%)$ respondentów niezależnie od płci, miejsca zamieszkania, wykształcenia, sytuacji zawodowej uznała, że jest to produkt o nowych, oryginalnych smakach. $Z$ całkowicie nowym produktem utożsamiło się $43,8 \%$ ankietowanych. $39,6 \%$ ankietowanych (w większości były to osoby do 40 roku życia), stwierdziło, że produkt innowacyjny to produkt funkcjonalny o korzystnym udokumentowanym oddziaływaniu na zdrowie. Kolejnymi skojarzeniami jakie podali respondenci były: ulepszona linia produktowa (30,2\%), zastosowanie ekologicznych surowców w procesie produkcji $(27,1 \%)$, produkt w nowym opakowaniu $(26 \%)$. W dużo mniejszym stopniu badani kojarzyli innowacje sektora owoców i warzyw z nowymi sposobami promocji $(14,6 \%), \mathrm{z}$ produktami już istniejącymi ale sprzedawanymi pod inną marką $(9,4 \%)$ oraz ze zmianą zasad działania przedsiębiorstwa $(6,3 \%)$.

Obecnie, konsumenci nie tylko oczekują od żywności zaspokojenia głodu, ale również pozytywnego wpływu na ich zdrowie, między innymi poprzez obniżenie poziomu cholesterolu, czy też zachowania równowagi mikroflory jelitowej. Ważny jest także innowacyjny skład, czyli wzbogacenie produktów w nowe składniki $(43,1 \%)$ jak i jego wyższa jakość (40,3\%). Cena jako czynnik motywujący bądź też demotywujący do zakupu deklarowana była przez 16,7\% badanych, natomiast reklama przez 13,9\% osób, zaś rekomendacja sprzedawcy lub znajomego przez 12,5\% opiniodawców. Pozostałe czynniki takie jak: moda, nowe funkcjonalne opakowanie czy zwiększony okres przydatności do spożycia były rzadziej wybierane przez respondentów i nie przekroczyły progu 7\%. Warto zaznaczyć, że to kobiety częściej podawały modę jako czynnik motywujący w porównaniu do mężczyzn, dla których zwiększony okres przydatności do spożycia był cenniejszy. Jako inny przykład ankietowani podali ciekawość nowości, jako czynnik motywujący do zakupu takich produktów (wykres 1).

Wykres 1. Oczekiwania respondentów wobec innowacyjnych produktów sektora owocowowarzywnego

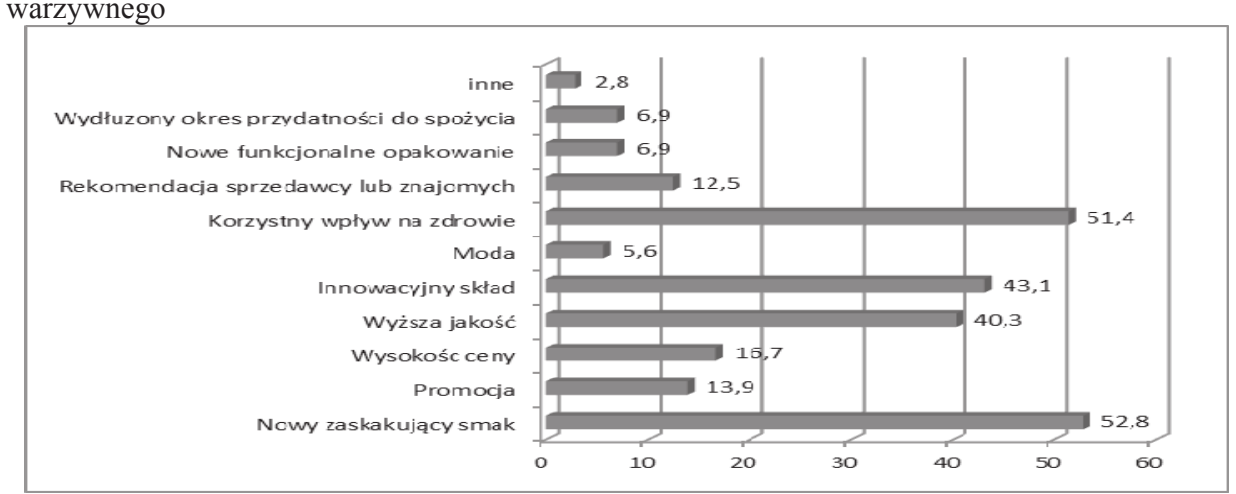

Źródło: Badanie własne. 
Deklaracje respondentów dotyczące podejścia do czynników związanych $\mathrm{z}$ procesem nabywania nowych produktów były bardzo zróżnicowane. Jak wynika z przeprowadzonych badań największą grupę wśród ankietowanych $(43,6 \%)$, stanowiły osoby deklarujące, że kupowali nowe produkty żywnościowe po wypróbowaniu ich przez znajomych i wyrażaniu przez nich pozytywnych opiniach o takich produktach. Prawdopodobnie wynika to $\mathrm{z}$ postrzeganego niskiego ryzyka nieudanego zakupu. Te osoby nazywane są zazwyczaj późnymi naśladowcami. Do grupy wczesnych naśladowców kupujących nowe produkty stosunkowo szybko należało 36,1\% ankietowanych. Osoby, które niechętnie nabywały innowacyjne produkty owocowo warzywne stanowiły niecałe $12 \%$ wskazań, a respondenci deklarujący, że byli tradycjonalistami i nie kupowali nowych produktów było zaledwie $4 \%$.

Respondenci najczęściej kupowali produkty uznane przez nich za innowacyjne kilka razy w miesiącu (41,7\% wskazań). Najliczniejszą grupa, która zaopatrywała się z taką systematycznością okazały się być osoby poniżej 40 roku życia, a w tym ponad połowa to osoby bardzo młode posiadające nie więcej niż 25 lat, a ponadto ich dochód nie był wyższy niż 2000 zł netto miesięcznie. Kilkukrotne zakupy w ciągu roku zadeklarowało $34,7 \%$ ankietowanych. Ponad $15 \%$ osób nabywało innowacyjne produkty sektora owoców i warzyw kilka razy w tygodniu. Rzadziej niż kilka razy w roku zaledwie $4,2 \%$, a codziennie jeszcze mniej bo $2,8 \%$ badanych. Zaobserwowano także zależność pomiędzy częstotliwością nabycia, a miejscem zamieszkania. Osoby mieszkające na wsi rzadziej nabywali innowacyjne produkty sektora owoców i warzyw, niż osoby mieszkające w mieście. Wynika to $\mathrm{z}$ większej dostępności na wsi tradycyjnych produktów, pochodzących z własnych upraw.

Najczęstszym miejscem nabywania takich produktów przez konsumentów były super i/lub hipermarkety - 70,8\% wskazań. Kolejnym dość znaczącym miejscem zakupu okazały się być sklepy dyskontowe $(48,6 \%)$. Pozostałe warianty odpowiedzi nie przekroczyły $20 \%$ deklaracji i były to bazary $(19,4 \%)$, osiedlowe sklepiki, sklepy z żywnością ekologiczna, sklepy internetowe (wszystkie trzy po 18,1\% wskazań), czy kiermasze i targi $(15,3 \%)$. W sklepach specjalistycznych taką żywność nabywało zaledwie $8,3 \%$ respondentów, a jeszcze mniej, bo $6,9 \%$ badanych w barach czy restauracjach.

Ankietowani zostali także zobligowani do określenia stopnia rozpoznawalności innowacji marketingowych i produktowych. 75\% respondentów była w stanie rozpoznać innowacje marketingowe, natomiast pozostali nie potrafili tego zrobić. Innowacje produktowe potrafiło określić aż $81,9 \%$ ankietowanych, a 18,1\% badanych z takowymi innowacjami miało problem. Na pytanie o najczęściej rozpoznawalne innowacje marketingowe ankietowani, wybierali w szczególności promowanie produktów przez liderów opinii czyli sławnych ludzi (46,3\% wskazań), reklama danego produktu w różnych miejscach spotykana była przez 44,4\% respondentów. Dostępność danego produktu w wielu miejscach deklarowało $40,7 \%$ badanych co potwierdza coraz bardziej rozbudowującą się sieć dystrybucji w Polsce. Zmienność szaty graficznej na etykietach i opakowaniach oraz promocje cenowe były wskazywane przez odpowiednio 33,3\% oraz $29,6 \%$ opiniodawców. Zmiana wizerunku marki i pozycjonowanie produktów w filmach lub programach telewizyjnych zadeklarowało 20,4\% ankietowanych. W tym przypadku zdecydowaną większością, która określiła te warianty były osoby starsze i osoby w średnim wieku, wiąże się to z większą możliwością i częstotliwością oglądania telewizji. 
11,1\%badanych uznało za innowacje stosowanie specjalnych ofert dla właścicieli kart lojalnościowych oraz otrzymywanie produktów w formie profitów (9,3\%), (wykres 2).

Wykres 2.Rodzaje innowacji postrzeganych przez nabywców w sektorze owoców i warzyw

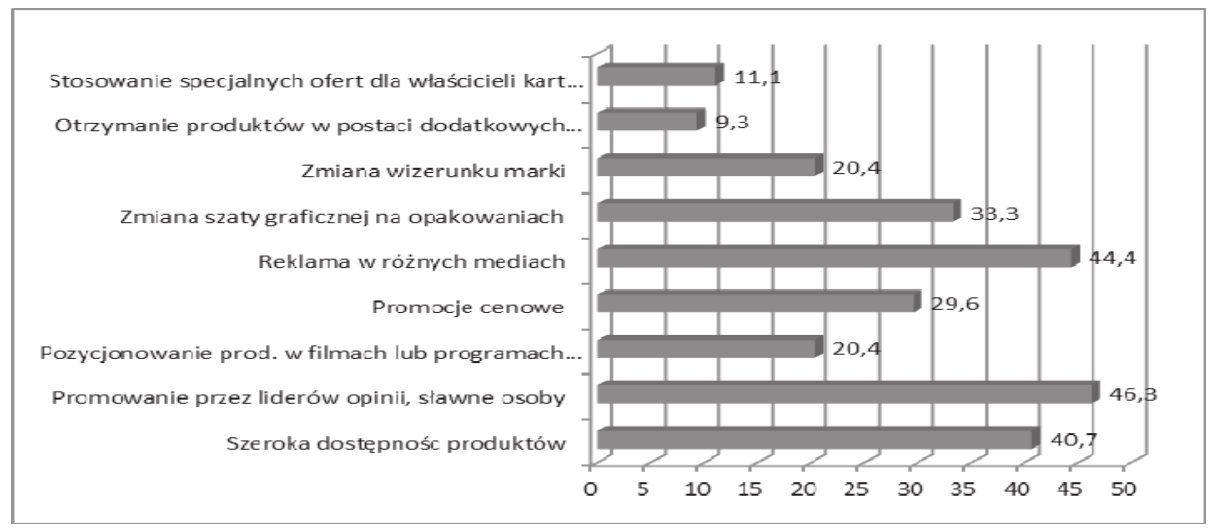

Źródło: Badanie własne.

Badani konsumenci oczekują jednak od innowacyjnych produktów korzystnego wpływu na zdrowie i zaskakujących smaków. Kolejnymi innowacjami jakie określili ankietowani była zmieniona ilość składników (47,5\%) oraz wprowadzenie na rynek zupełnie nowego produktu $(42,4 \%)$. Zmienioną recepturę produktu zadeklarowało $35,6 \%$ badanych przeważająca cześć to osoby młode. Grupa 32,2\% respondentów określiła stosowanie przyjaznych dla środowiska materiałów produkcyjnych jako istotne innowacje, a nowe zastosowanie istniejącego już produktu $28,8 \%$ osób. Zaledwie $6,8 \%$ badanych uważa za ważną innowacje produktową możliwość dowozu produktu w wyznaczone miejsce (wykres 3).

Wykres 3. Rodzaje innowacji marketingowych rozpoznawanych w sektorze owoców i warzyw

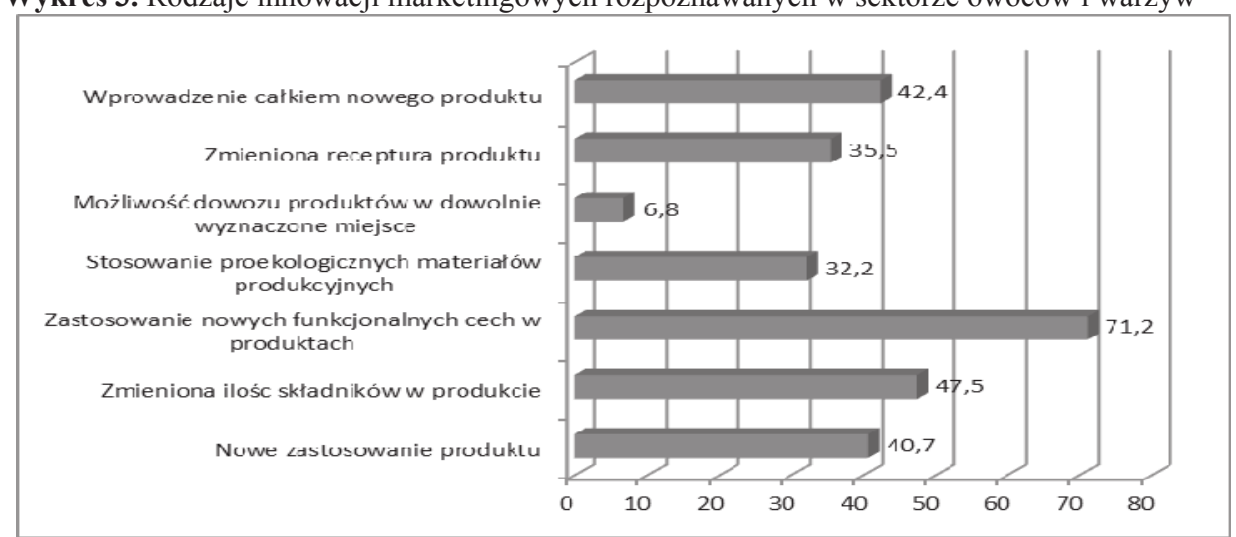

Źródło: Badanie własne. 


\section{Źródla informacji o produktach innowacyjnych}

Najczęstszym źródłem czerpania informacji o innowacyjnych produktach owocowych i warzywnych przez respondentów okazały się być wiadomości zawarte w internecie. Taką możliwość wybrało aż $60,4 \%$ ankietowanych, a ponad $80 \%$ z tych odpowiedzi wybrali ludzie młodzi poniżej 40 roku życia, w tym zdecydowaną większością były osoby poniżej 25 lat, dla których internet w obecnych czasach stał się nieodzownym elementem życia.

Prawie połowa badanych czerpała wiedzę $\mathrm{z}$ własnych obserwacji sklepowych $(47,9 \%)$, były to w znacznej większości osoby z wykształceniem wyższym. Niewiele mniej, bo $41,7 \%$ respondentów wskazywało na telewizję i na informacje zawarte na opakowaniach (30,2\%). Można stwierdzić, że współcześnie, w dobie wszechobecnego Internetu $\mathrm{w}$ zachowaniu obywateli dostrzega się jednak silną potrzebę dotknięcia produktu i zweryfikowania, czy informacje o promowanych produktach są zgodne z informacjami zawartymi w tradycyjnych mediach, a dodatkowo przeczytać informacje zawarte na etykietach. Kolejnymi źródłami wybieranymi przez ankietowanych była rodzina i znajomi (21,9\%), którzy zazwyczaj posiadają cechy liderów opinii i w znacznym stopniu wpływają na postawy innych konsumentów, prasa $(14,6 \%)$ oraz szkoła i studia $(14,6 \%)$. Zaledwie $8,3 \%$ badanych wybrało radio, a $6,3 \%$ respondentów jarmarki i bazary kojarzone bardziej z żywnością tradycyjną, aniżeli z produktami innowacyjnymi.

Badani respondenci mimo wielu pozytywnych cech związanych z innowacjami na rynku przetworów owcowo-warzywnych, wskazywali jednak również na bariery ograniczające możliwości zakupu tych produktów. Pierwszym i zdecydowanie najliczniejszym wskazaniem respondentów było określenie, że wolą produkty tradycyjne $(66,7 \%)$, natomiast drugim była ich wysoka cena $(37,5 \%)$. Kolejnymi ważnymi barierami były: nieznajomość wielu innowacyjnych produktów owocowych i warzywnych na rynku $(29,2 \%)$, brak wiedzy bezpośrednio na ich temat $(25 \%)$ oraz trudność w rozróżnieniu jej od innej żywności (20,8\%). Często konsumenci mają obawy przez nieznanym produktem. W mniejszym stopniu przeszkodą okazała się być opinia innych oraz niewiedza o możliwościach nabycia takich produktów (po 12,5\% odpowiedzi).

\section{Podsumowanie}

Przedsiębiorstwo, aby odnosić sukcesy a przede wszystkim zaspokoić potrzeby klientów musi wprowadzać nowe produkty lub doskonalić obecne. Odbywa się to poprzez wprowadzanie innowacji w technologii produkcji, modyfikację składu, zmianę opakowań. Zmieniająca się ciagle moda, trendy, styl życia konsumentów spowodowały, że oczekują oni nie tylko zaspokojenia swoich potrzeb, ale także osiagnięcia dodatkowych korzyści ze spożywania innowacyjnej żywności. Jednocześnie spore znaczenie przy dokonywaniu zakupu mają opinie innych, ceny, czy dostępność takich produktów. Producenci zobligowani są do poznania czynników psychospołecznych, marketingowych, demograficzno-ekonomicznych, społeczno-kulturowych, które w znacznej mierze wpływają na zachowania konsumentów na rynku innowacyjnych produktów. Nasycony już rynek spożywczy stawia coraz wyższe wymagania 
konsumentów wobec dostępnych na nich produktów spożywczych. Taka żywość musi posiadać odpowiednie walory jakościowe, dietetyczne, a przede wszystkim sensoryczne.

Przeprowadzone badanie empiryczne, na podstawie którego określono bariery, motywy, trendy oraz zachowania konsumentów na rynku innowacyjnych produktów owoców i warzyw. Badani w zdecydowanej większości kojarzyli innowacje sektora owoców i warzyw z produktem całkowicie nowym, o nowych i oryginalnych smakach.

Dla dużej liczby respondentów informacje zamieszczone na opakowaniu były podstawą do określenia, że dany produkt to produkt innowacyjny, natomiast najczęstszym źródłem czerpania wiedzy o tych produktach okazał się być Internet. Wiedza konsumentów na temat innowacyjnych produktów owocowych i warzywnych była zadowalająca. Mimo wszystko stwierdzono spore możliwości, aby tę wiedzę poszerzać poprzez częstsze reklamy i akcje marketingowe. Natomiast wiedza związana bezpośrednio z innowacjami produktowymi oraz marketingowymi sektora owocowowarzywnego osiagnęła dosyć wysoki poziom znajomości.

Respondenci nabywali innowacyjne produkty kilka razy w miesiącu zważywszy na ich wyróżniające się właściwości poprawiające zdrowie czy samopoczucie. Konsumenci kupowali innowacyjne produkty owocowo-warzywne najczęściej w super i hipermarketach. Spowodowane jest to bogatą ofertą produktową i dość szerokim asortymentem dostępnych produktów.

Przekazywane informacje o innowacjach wpływają na adaptację tych produktów przez konsumentów. Stąd większość ankietowanych korzystała z własnych obserwacji, a istotnym czynnikiem motywującym badanych do zakupu ich pozytywny wpływ na zdrowie.

Badania wykazały również jedną główną barierę nabywania innowacyjnych produktów sektora owoców i warzyw, a była to większa chęć do spożywania tradycyjnych i już sprawdzonych produktów.

\section{Bibliografia}

Barczak B., Walas-Trębacz J.: Działalność innowacyjna sektora MSP - determinanty rozwoju. Prace i Materiały Wydziału Zarządzania Uniwersytetu Gdańskiego 2005, nr 4.

Baruk J.: Zarzqdzanie wiedzq i innowacjami. Wydawnictwo Adam Marszałek, Torun 2006.

Czapski J.: Owoce $i$ warzywa oraz ich przetwory. W: Żywność prozdrowotna - składniki i technologia (red. J, Czapski, D. Górecka). Wydawnictwo Uniwersytetu Przyrodniczego w Poznaniu, Poznań 2015.

Grębowiec M.: Znaczenie innowacji produktowych $w$ rozwoju przedsiębiorstw na przykładzie branzy owocowo-warzywnej. Zeszyty Naukowe Szkoły Głównej Gospodarstwa Wiejskiego w Warszawie - Problemy Rolnictwa Światowego 2011, 11(26), nr 2.

Grzybowska B.: Innowacyjność przemystu spożywczego - ujęcie regionalne. Wydawnictwo UWM, Olsztyn 2012.

Jeżewska-Zychowicz M.:, Uwarunkowania akceptacji konsumenckiej innowacyjnych produktów żywnościowych. Żywność. Nauka. Technologia. Jakość 2014, 6(97).

Kruczyńska D. : Nowe odmiany jabłoni. Wydawnictwo Hortpress, Warszawa 2008.

Lemanowicz M.: Aktywność innowacyjna przedsiębiorstw w Polsce ze szczególnym uwzględnieniem branży spożywczej. Roczniki Naukowe Stowarzyszenia Ekonomistów Rolnictwa i Agrobiznesu 2014, 16(6).

Oslo Manual : Guidelines for Collecting and Interpreting Innovation Data. 3rd Edition. OECD and Eurostat 2005. 
Szymańska A. I.: Innowacyjność produktowa przedsiębiorstw produkcyjnych a preferencja konsumentów. Prace Komisji Geografii Przemysłu Polskiego Towarzystwa Geograficznego, 2012(20).

Targosz R.: Promocja innowacyjnych rozwiazań technicznych i organizacyjnych $w$ sektorze przetwórstwa żywności. Wydawnictwo SGGW, Warszawa 2015.

Tylżanowski R.: Determinanty innowacyjności polskich przedsiębiorstw. W: Innowacyjność organizacji $w$ strategii intelektualnego $i$ zrównoważonego rozwoju (red. J. Wiśniewska, K. Janasz). Wydawnictwo Difin Warszawa. 2012.

www.portalspozywczy.pl/owoce-warzywa/wiadomosci/sektor-owocow-i-warzyw-rozwija-sie-wrytmie-convenience,138286.html, dostęp $w$ dniu 18.06.2017 r.

\section{Summary}

Fashion, health and convenience shape today's consumer market in innovation. The knowledge of the consumer is the key to the success of the company. The aim of the study was to evaluate the innovativeness of the fruit and vegetable sector in Poland in the opinion of Polish consumers. Based on the available literature, articles and professional journals and the information published on websites characterized by changes in the Polish market in fruit and vegetables, innovative fruit and vegetable sector, types of innovation related to new technologies and processes, and new methods of marketing and organizational and also described trends and consumer barriers in the fruit and vegetable sector. For a full presentation of the degree of knowledge and recognition of selected innovations and the relation to this type of products of the consumer survey was conducted.

Keywords - innovation, market, consumer, fruit and vegetables, innovative food products.

Informacje o autorze

Dr inz. Mariusz, Grębowiec

Szkoła Główna Gospodarstwa Wiejskiego w Warszawie

Wydział Nauk Ekonomicznych

Katedra Polityki Europejskiej i Marketingu

ul. Nowoursynowska 166, 02-787 Warszawa

tel. 225234088

e-mail: mariusz grebowiec@sggw.pl

ORCID: 0000-0002-2631-3940 